\title{
Influence of Environmental Factors on Forest Understorey Species in Northern Mexico
}

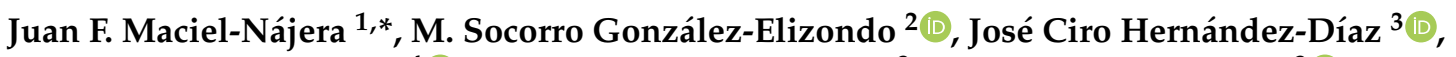 \\ Carlos A. López-Sánchez ${ }^{4}\left(\mathbb{D}\right.$, Claudia Edith Bailón-Soto ${ }^{3}$, Artemio Carrillo-Parra ${ }^{3} \mathbb{C}$ and Christian Wehenkel ${ }^{3}$ \\ 1 Programa Institucional de Doctorado en Ciencias Agropecuarias y Forestales, \\ Universidad Juárez del Estado de Durango, Durango 34120, Mexico \\ 2 Centro Interdisciplinario de Investigación para el Desarrollo Integral Regional, Instituto Politécnico Nacional, \\ Durango 34234, Mexico; herbario_ciidir@ipn.mx \\ 3 Instituto de Silvicultura e Industria de la Madera, Universidad Juárez del Estado de Durango, Durango 34120, \\ Mexico; jciroh@ujed.mx (J.C.H.-D.); claudia.bailon@ujed.mx (C.E.B.-S.); acarrilloparra@ujed.mx (A.C.-P.); \\ wehenkel@ujed.mx (C.W.) \\ 4 Department of Biology of Organisms and Systems, Mieres Polytechnic School, \\ University of Oviedo, 33600 Mieres, Spain; lopezscarlos@uniovi.es \\ * Correspondence: macielnjf@ujed.mx
}

Citation: Maciel-Nájera, J.F.; González-Elizondo, M.S.; Hernández-Díaz, J.C.; López-Sánchez, C.A.; Bailón-Soto, C.E.; Carrillo-Parra, A.; Wehenkel, C. Influence of Environmental Factors on Forest Understorey Species in Northern Mexico. Forests 2021, 12, 1198. https://doi.org/10.3390/ f12091198

Academic Editor: Eustaquio Gil-Pelegrín

Received: 2 August 2021

Accepted: 30 August 2021

Published: 3 September 2021

Publisher's Note: MDPI stays neutral with regard to jurisdictional claims in published maps and institutional affiliations.

Copyright: (C) 2021 by the authors. Licensee MDPI, Basel, Switzerland. This article is an open access article distributed under the terms and conditions of the Creative Commons Attribution (CC BY) license (https:/ / creativecommons.org/licenses/by/ $4.0 /)$.
Abstract: Background: Understorey plants are key to maintaining forest structure and functioning. They protect the soil, improve its structure and fertility, reduce water run-off and sustain the belowground biota, amongst other ecological services. However, little is known about the environmental conditions that regulate the occurrence of these plants. This study focuses on determining how canopy cover influences the occurrence of understorey species and identifying the most important soil properties that affect these species. The study area was a pine-oak forest in the Sierra Madre Occidental, an important source of ecological services for northwestern Mexico. Methods: To assess the conditions influencing the presence of herbaceous and shrub species, 25 soil variables were examined in relation to the species occurring in forest gaps and under the canopy. Sampling was conducted in five plots, each of $100 \times 100 \mathrm{~m}$. In each plot, 4 subplots, each of $20 \times 20 \mathrm{~m}$, were each subdivided in a grid of $2 \times 2 \mathrm{~m}$ units, in which the presence-absence of herbaceous and shrub species was recorded (2000 units in total). Soil samples were extracted for analysis from the central point in each subplot. Data were analyzed using a Binomial Logistic Model (BLM) and Random Forest (RF) classification. Results: Understorey species were more strongly affected by soil variables than by their location in gaps or below canopy. The concentrations of $\mathrm{Ca}, \mathrm{P}, \mathrm{K}, \mathrm{Fe}, \mathrm{Na}, \mathrm{C}, \mathrm{Zn}, \mathrm{Mn}$, nitrates, organic matter, sand, silt, and percentage water saturation were statistically significantly associated with the presence of some plant species, whilst no significant differences were found in regard to preference for gaps or canopy, although several species were more frequent in open areas. Conclusions: Given the importance of the understorey cover in forest system functioning, we propose that understorey should be considered in integrated management and conservation practices for the temperate forests of northern Mexico.

Keywords: BLM; random forest; environmental; soil; canopy forest; gap forest

\section{Introduction}

The composition and distribution of vegetation are influenced by many factors, including abiotic environmental factors (e.g., humidity, temperature, rainfall, wind and soil) and physiographic factors (e.g., slope, exposure, altitude and latitude) [1-4]. These factors control growth, plant spatial patterns and diversity and hence have local and regional effects on plant communities [5-8].

Vegetation is one of the main components of forest ecosystems and it is therefore essential to determine the ecological requirements of the component plants [9-11]. Forest cover 
has a strong effect on air temperature and humidity; microclimatic conditions and forest structure are strongly correlated and influence understorey plant development [12,13].

Understorey plants are important for maintaining the structure and function of forests and contribute to ecosystem dynamics. They protect and conserve the soil, improve its structure and fertility, enhance nutrient cycling, reduce water run-off and sustain the belowground biota, among other ecological services [14-18]. However, the understorey is one of the least understood components of the forest, and understorey composition, diversity and ecological role, together with the factors regulating the ecological processes, remain relatively unknown [14,19-21].

Most of the resources required for plant development are found in the soil $[12,17,22-25]$, and soil physical and chemical properties strongly influence species composition at the local scale $[12,16,17]$, while influencing tree distribution even more strongly than climate in some temperate forests [9]. Therefore, climate and soil variables are together strong predictors of the occurrence of some plant species. The relationships between tree species and soil physical and chemical properties has been addressed in several studies on temperate forests; for example, with Pinus and Quercus trees $[18,26]$ and considering natural regeneration patterns [27-30]. In our study zone, research has mainly focused on forest dynamics [30-33], and we could not find any research related to environmental factors that influence herbaceous and shrub species Hence, further research is needed to clarify the relationships between tree species and understory plants, along with their spatial patterns [34,35].

In Mexico, mountain ranges are mainly covered by temperate forests dominated by pines (Pinus) and oaks (Quercus) [36-38]. These are also the main tree elements in the Sierra Madre Occidental (SMO), which is the largest mountain massif in the country. The SMO harbours more than 27 million hectares of temperate pine-oak forest [7], with two thirds of the standing timber in Mexico [39]. The SMO provides ecological and environmental services on which most of the population of northwestern Mexico depends [40], and it is considered one of the world's top 34 biodiversity hotspots [41]. Although much research has been conducted in relation to tree species and forest productivity in this region, there is a wide gap of information regarding the lower strata of the forest and the ecological factors influencing the species concerned.

The aims of this study were to determine whether the presence-absence of canopy cover influences the occurrence of shrub and herbaceous species and to identify which edaphic factors most strongly influence those species in a temperate mixed Pinus-Quercus forest in the Sierra Madre Occidental, northwestern Mexico. As most subtropical forests, the ones we studied are uneven-aged due to natural reasons: in a continuous way, the fall of one or a few trees open gaps in which new regeneration starts [28]. These forests additionally differ from the usually even-aged forests from colder climates in being more diverse, each species having different growth dynamics $[7,40]$ and only some of them being affected by certain diseases; the fires are more frequent and usually not catastrophic, and the terrains where they grow are very rugged, the many microhabitats giving different outcomes.

We posed three research questions: (a) which soil components and properties are most closely associated with the understorey species? (b) does the presence-absence of canopy cover influence the occurrence of the species in the understorey?, and (c) do soil variables explain the species presence under the canopy and in the gaps?

\section{Materials and Methods}

\subsection{Study Area}

The study area is located in the Sierra Madre Occidental range, in the municipality of Madera, northwest of the state of Chihuahua, Mexico (Figure 1), between coordinates $28^{\circ} 41^{\prime} 18^{\prime \prime}$ to $30^{\circ} 0^{\prime} 14^{\prime \prime} \mathrm{N}$ and $107^{\circ} 47^{\prime} 6^{\prime \prime}$ to $108^{\circ} 45^{\prime} 13^{\prime \prime} \mathrm{W}$, at elevations of 2189 to $2580 \mathrm{~m}$ (Table 1), in the same general area where a previous study on regeneration was conducted [28]. The study area is covered by natural pine-oak forest sharing the same 
ecological and biogeographical affinities; the area also shares a similar geological origin and physiography (non-pronounced slopes), with few differences in exposure and elevation, as ravines and high elevations were avoided. The forests in this area include associations of Pinus arizonica Engelm., P. durangensis Martínez, P. engelmannii Carr., P. leiophylla Schltdl. \& Cham., P. strobiformis Engelm., Arbutus arizonica Sarg., A. xalapensis Kunth s.l., Juniperus deppeana Steud., Quercus sideroxyla Humb. \& Bonpl. and Q. arizonica Sarg. [40,42,43]. The tree densities recorded for the five local rural communities studied (Ejidos: "Madera", "La Norteña", "El Oso, La Avena y Anexos", "Colonia Nicolás Bravo 2", and "Ejido Socorro Rivera"), correspond to 764, 488, 981, 383 and 1573 trees per hectare, respectively [28], and relatively low heights, of $9.1,12,8.1,15$, and $7.2 \mathrm{~m}$, respectively. The mean annual temperature varies between 9.3 and $11.1^{\circ} \mathrm{C}$; average annual precipitation ranges between 650 and $969 \mathrm{~mm}$, and the soil is acidic, of pH 5.4 to 6.1 [44].

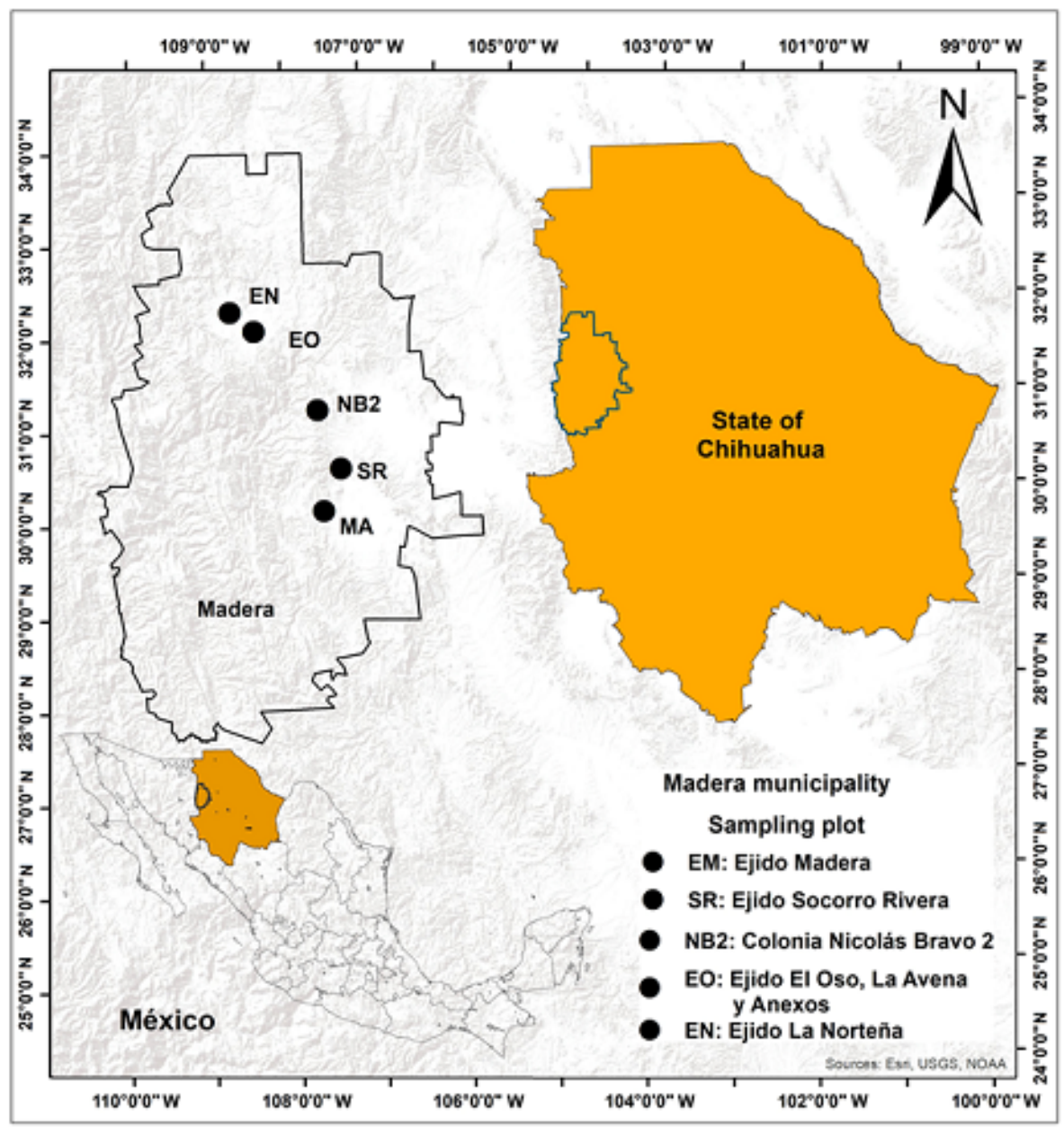

Figure 1. Location of the five $100 \times 100 \mathrm{~m}(1 \mathrm{ha})$ sampling plots in the municipality of Madera, Chihuahua, Mexico. Source: Own elaboration using ArcGis software available at Esri, DigitalGlobe, GeoEye, Earthstar Geographics, CNES/Airbus DS, USDA, USGS, AEX, Getmapping, Aerogrid, IGN, IGP, swisstopo, and the GIS User Community). Maps were created using ArcGIS®software by Esri. Copyright @Esri. All rights reserved [45]. 
Table 1. Geographical coordinates of the plot samples in the study area.

\begin{tabular}{cccccc}
\hline Plot & Geographical Coordinates & $\begin{array}{c}\text { MAP } \\
(\mathbf{m m})\end{array}$ & $\begin{array}{c}\text { MAT } \\
\left({ }^{\circ} \mathbf{C}\right)\end{array}$ & $\begin{array}{c}\text { Elevation } \\
(\mathbf{m})\end{array}$ & $\begin{array}{c}\text { Geographical } \\
\text { Exposure }\end{array}$ \\
\hline Ejido Madera & $29^{\circ} 12^{\prime} 15.92^{\prime \prime} \mathrm{N},-108^{\circ} 11^{\prime} 04.20^{\prime \prime} \mathrm{W}$ & 827 & 9.7 & 2481 & $\mathrm{E}$ \\
Ejido La Norteña & $29^{\circ} 39^{\prime} 04.50^{\prime \prime} \mathrm{N},-108^{\circ} 24^{\prime} 51.70^{\prime \prime} \mathrm{W}$ & 821 & 10.9 & 2189 & $\mathrm{SW}$ \\
Ejido El Oso, La Avena y & $29^{\circ} 36^{\prime} 29.40^{\prime \prime} \mathrm{N},-108^{\circ} 21^{\prime} 15.50^{\prime \prime} \mathrm{W}$ & 801 & 10.7 & 2212 & $\mathrm{~N}$ \\
Anexos & $29^{\circ} 25^{\prime} 46.60^{\prime \prime} \mathrm{N},-108^{\circ} 11.0^{\prime} 42.2^{\prime \prime} \mathrm{W}$ & 849 & 9.3 & 2580 & $\mathrm{~N}$ \\
Colonia Nicolás Bravo 2 & $29^{\circ} 17^{\prime} 54.57^{\prime \prime} \mathrm{N},-108^{\circ} 08^{\prime} 21.0^{\prime \prime} \mathrm{W}$ & 650 & 11.1 & 2210 & $\mathrm{~W}$ \\
Ejido Socorro Rivera & & 789.6 & 10.34 & 2334 & \\
\hline Mean & &
\end{tabular}

where MAT $=$ Mean annual temperature $\left({ }^{\circ} \mathrm{C}\right)$ and MAP $=$ Mean annual precipitation $(\mathrm{mm})$.

\subsection{Data Collection}

\subsubsection{Sampling Sites}

Field sampling and data collection were carried out in two different periods. In AugustSeptember 2016, the soil samples were collected and the study sites were established [28], and in August-September 2018, the understory species were recorded in each plot. This time of the year was chosen since it is when most of the plants in the area bear reproductive structures, necessary for correct taxonomic identification. The presence of shrubs and herbaceous species was determined by direct observation, and those species not identified in situ were classified and recorded using digital photographs and collections. Samples and images were identified using a preliminary checklist and from taxonomic literature and databases. The records were included in the database of the CIIDIR herbarium in Durango, Mexico [46].

Five $100 \times 100 \mathrm{~m}$ plots were established in five previously randomly selected forest communities in four "ejidos" and one "colonia", rural communities where the holders are entitled to share all the benefits [47]. Each plot included four $20 \times 20 \mathrm{~m}$ subplots, each located in the centre of the quarter of the plot. To determine the variables influencing the occurrence of understorey plant species in the gaps and below the canopy, a grid of 100 units of $2 \times 2 \mathrm{~m}$ was marked from the centre of each of the 20 subplots (2000 units in total) (Figure 2). In each of these $2 \times 2 \mathrm{~m}$ units the occurrence of herbaceous and shrub species was recorded, and the location of the species under the canopy or in a gap was also recorded.

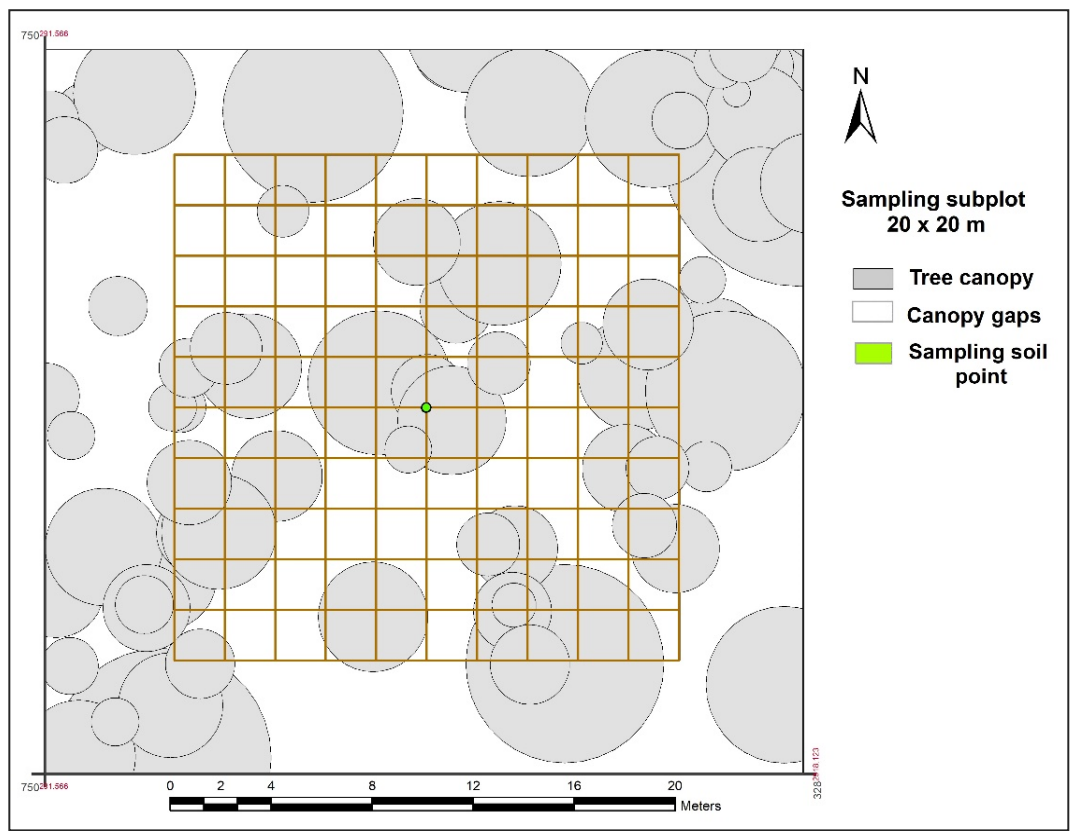

Figure 2. Delimitation of subplots $(20 \times 20 \mathrm{~m})$ and $2 \times 2 \mathrm{~m}$ units, to determine the presence of understorey species below the forest canopy and in the gaps. 
To evaluate how the soil variables, forest canopy and gaps influence the occurrence of the understorey species, we selected the 22 most conspicuous species (those that were easily recognized in the field, in order to prevent mistakes in records) (see Table 2). The canopy coverage and gaps were delimited within each sampling plot by using ArcGIS version 10.0 [45].

Table 2. Occurrence of species in gaps and under the canopy.

\begin{tabular}{|c|c|c|c|c|c|c|c|}
\hline Species & Gap $(n)$ & Canopy $(n)$ & Mean & $\begin{array}{c}\text { Gap } \\
(n \text { in } \%)\end{array}$ & $\begin{array}{l}\text { Canopy } \\
(n \text { in \%) }\end{array}$ & $\begin{array}{c}\text { Chi-Square } \\
\text { Statistics }\end{array}$ & $p$-Value \\
\hline Viola grahamii Benth. & 19 & 28 & 23.5 & 4.85 & 5.27 & 0.15 & 0.70 \\
\hline Phaseolus parvulus Greene & 19 & 49 & 34.00 & 4.85 & 9.23 & 2.23 & 0.14 \\
\hline Stevia serrata Cav. & 105 & 122 & 113.5 & 26.79 & 22.98 & 0.04 & 0.84 \\
\hline Lupinus diehlii M.E. Jones & 8 & 14 & 11.00 & 0.87 & 1.52 & 0.11 & 0.74 \\
\hline Cologania obovata Schltdl. & 159 & 200 & 179.5 & 17.23 & 21.67 & 0.09 & 0.77 \\
\hline Cologania angustifolia Kunth & 75 & 112 & 93.5 & 8.13 & 12.13 & 0.16 & 0.69 \\
\hline Chimaphila maculata (L.) Pursh & 0 & 3 & 1.50 & 0.00 & 0.33 & 3.16 & 0.08 \\
\hline Oxalis metcalfei (Small) R. Knuth + O. hernandezii DC. & 45 & 72 & 58.5 & 4.88 & 7.80 & 0.51 & 0.48 \\
\hline Geranium wislizeni S. Watson & 25 & 13 & 19.00 & 2.71 & 1.41 & 0.11 & 0.74 \\
\hline Commelina dianthifolia Delile & 96 & 94 & 95.00 & 10.4 & 10.18 & 0.01 & 0.93 \\
\hline Acmispon wrightii (A. Gray) Brouillet & 7 & 15 & 11.00 & 0.76 & 1.63 & 0.09 & 0.77 \\
\hline Cyperus sphaerolepis Boeck. & 56 & 28 & 42.00 & 6.07 & 3.03 & 2.40 & 0.12 \\
\hline Pseudognaphalium arizonicum (A. Gray) Anderb. & 33 & 11 & 22.00 & 3.58 & 1.19 & 1.94 & 0.16 \\
\hline Verbesina parviflora S.F. Blake & 0 & 1 & 0.50 & 0.00 & 0.11 & 1.00 & 0.32 \\
\hline $\begin{array}{c}\text { Penstemon miniatus var. townsendianus (Straw) } \\
\text { C.C.Freeman }\end{array}$ & 0 & 6 & 3.00 & 0.00 & 0.65 & 4.32 & 0.04 \\
\hline Agastache pallida (Lindl.) Cory & 13 & 1 & 7.00 & 1.41 & 0.11 & 4.69 & 0.03 \\
\hline Packera candidissima (Greene) W.A. Weber \& A. Löve & 103 & 134 & 118.50 & 11.16 & 14.52 & 0.05 & 0.82 \\
\hline Milla biflora Cav. & 5 & 0 & 2.50 & 0.54 & 0.00 & 1.00 & 0.32 \\
\hline Ratibida mexicana (S. Watson) W.M. Sharp & 42 & 15 & 28.50 & 4.55 & 1.63 & 0.11 & 0.74 \\
\hline Arctostaphylos pungens Kunth & 8 & 3 & 6.50 & 0.86 & 0.54 & 0.01 & 0.92 \\
\hline Ceanothus depressus Benth. & 55 & 128 & 91.50 & 5.96 & 13.87 & 0.82 & 0.36 \\
\hline Ceanothus coeruleus Lag. & 25 & 29 & 27.00 & 2.71 & 3.14 & 0.01 & 0.91 \\
\hline
\end{tabular}

where: $n=$ presence.

2.2.2. Determining the Presence of Understorey Species, Soil Variables and Canopy

To study the effect of soil properties on understory species, a sample of $1000 \mathrm{~g}$ was collected from the centre of each of the 20 subplots at $15 \mathrm{~cm}$ depth (four samples by plot); a total of 11 soil samples were obtained from the canopy cover and 9 from the gaps. In total, 25 soil variables were analyzed according to the methodology described by DominguezGuerrero et al. [48]: concentrations (ppm) of potassium (K), magnesium (Mg), sodium $(\mathrm{Na})$, copper $(\mathrm{Cu})$, iron $(\mathrm{Fe})$, zinc $(\mathrm{Zn})$, calcium $(\mathrm{Ca})$, manganese $(\mathrm{Mn})$ and phosphorus $(\mathrm{P})$, concentration of nitrate $\left(\mathrm{NO}_{3}, \mathrm{~kg} / \mathrm{ha}\right), \mathrm{pH}$, cation exchange capacity (CEC, meq/100 g soil), organic matter (\%) and texture (\%), among others (Table S1).

The soil did not differ significantly among sites across gaps or under the canopy. The texture ranged as follows: sand (35.42-63.42\%), clay (9.3-23.3\%) and silt (19.28-45.28\%). The organic matter $(\mathrm{OM})$ content ranged from $0.66-14.2 \%$ and the percentage water saturation from 29.5 to $80 \%$.

\subsection{Data Analysis}

The 22 plant species were recorded and categorized with values of " 0 " for absence and " 1 " for presence in each of the $20002 \times 2 \mathrm{~m}$ units for correlation with the gaps and canopy. The relationship between species and soil variables was analyzed considering their frequency (which was directly obtained from the number of units/100 where each species was recorded). This grouping was established to avoid pseudoreplication, given that only one soil sample was obtained in each $20 \times 20 \mathrm{~m}$ subplot. In order to detect collinearity between variables, the Spearman correlation coefficient ( $r$ ) was determined using the "cor.test" function. When the $r$ Value between two soil variables was greater than an absolute value of 0.7 , one of the variables was excluded from the analysis in order to prevent collinearity. The variable with the lowest significance value obtained from the regression analysis was used for model fitting. The statistical significance in difference 
of median unit number with species presence per subplot between canopy and gaps was analyzed by the Kruskal-Wallis test (after Bonferroni correction $\alpha=0.0025$ ). In this case, only those $2 \times 2 \mathrm{~m}$ units that represented a full gap or full canopy were considered $(46.15 \%$ of the total 2000 units). However, for the subsequent analysis and modelling, all of the units were included (under canopy, partially under canopy and those in the gaps).

To determine the probability of association between the presence-absence of the understorey species with the edaphic variables and the canopy or gaps, we used a binomial logistic regression model (BLM) [49]. The accuracy of the BLM was determined by the Akaike Information Criterion (AIC) (within each species), residual deviation (RD) and null deviation (ND). The deviance is an important indicator for determining the goodness of fit of the models and is obtained by ANOVA, which compares the predicted and observed values, with greater precision in the model prediction capacity when the residual deviance is less than the null deviation [50]. Appropriate independent variables for the BLM were found using the stepAIC stepwise function in the "MASS" package, in which variables are added to create a reduced initial model that minimizes the AIC value of the models [51,52].

The probability of presence ( $\mathrm{PoP}$ ) of a given species with the studied variables was estimated with the BLM model [49], as follows:

$$
\mathrm{PoP}=\frac{1}{1+e^{a_{1} \operatorname{var}_{1}+a_{2} \operatorname{var}_{2}+a_{3} \operatorname{var}_{3}+\ldots i+b}}
$$

where $\mathrm{a}_{1,2,3}$ are the model parameters, $\operatorname{var}_{1,2,3}$ are the independent variables, and $b$ is the model intercept.

In order to reduce the variation, we used the non-parametric random forest (RF) technique, with 5 -fold cross-validation $(\mathrm{CV})$, this term indicates that the $80 \%$ of the data are used by model and, the $20 \%$ of the data represent the model validation, which allows rapid, efficient identification of the most important variables for the model [53,54].

The relative variable importance was determined by the Partial Least Squares (PLS) based on the weighted sums of the absolute regression coefficients using the importance function in "Random Forest" packages. PLS is an analytical method applicable when the data include more predictions than observations, and it is used to estimate the importance of a predictor variable in a model regression [55-57]. In RF, the most commonly used method to analyze the variable importance is the mean decrease in Gini, where the importance value is expressed as a percentage; this corresponds to the mean variable total decrease in node impurity, weighted by the proportion of samples reaching that node in each decision tree in RF, i.e., normalization of importance values [49].

The RF model performance was estimated using Receiver Operating Characteristic (ROC) analysis, which indicates the quality of the model by the relationship between true and false positives obtained in the validation set, with specificity and sensitivity [53] and true skill statistics (TSS) [58]. The sensitivity measures the proportion of actual positives that are correctly identified, while the specificity measures the proportion of actual negatives that are correctly identified. TSS compares the number of correct forecasts taking into consideration both commission and omission errors and successes, as a result of random guessing, where +1 indicates perfect agreement between forecast and reality and values of zero or below indicates a performance no better than random (for more information, see Allouche et al. [58]).

The BLM and RF classification models were applied using the train, $\mathrm{rf}$ and glm (binomial family) functions of the "caret" package [59]. All analyses were performed with the free statistics application R [60].

\section{Results}

Relationships between the Presence of Understorey Species and Soil Variables and Lack of Association with Forest Canopy and Gaps

Analysis of the occurrence of herbaceous and shrub species in the five sampling plots revealed that the species presence is influenced by 22 soil variables, but not by 
position under the canopy or in the gaps, as indicated by the Kruskal-Wallis test, including Bonferroni correction (Table 2).

Soil variables strongly influenced (up to $36 \%$ ) the presence-absence of understory species, as shown by the Spearman correlation (Table 3). The binomial logistic regression model indicated that some species were positively correlated, showing a weak but significant association $(\alpha=0.0025)$ with some physical and chemical soil properties.

Table 3. Spearman correlation analysis between soil properties and plant species obtained for the Binomial Logistic Regression Model.

\begin{tabular}{|c|c|c|c|c|c|c|c|c|c|c|c|c|c|c|c|c|c|c|}
\hline Species & EC & $\mathbf{P}$ & $\mathrm{Ca}$ & $\mathrm{Mg}$ & $\mathrm{K}$ & $\mathrm{Fe}$ & $\mathrm{Zn}$ & $\mathrm{Cu}$ & OM & Sat & Sand & Silt & Clay & $\%$ Ca & $\% \mathrm{~K}$ & $\% \mathrm{Mg}$ & CEC & $\mathrm{HC}$ \\
\hline Viola grahamii & 0.01 & 0.52 & -0.39 & -0.31 & -0.36 & -0.25 & 0.17 & -0.23 & -0.24 & -0.31 & -0.06 & 0.04 & 0.05 & -0.24 & 0.03 & 0.02 & -0.38 & -0.12 \\
\hline Phaseolus paroulus & -0.58 & -0.56 & -0.55 & -0.37 & 0.45 & -0.45 & -0.49 & -0.27 & 0.37 & 0.47 & 0.31 & 0.03 & -0.66 & -0.68 & 0.72 & 0.09 & -0.47 & 0.07 \\
\hline Stevia serrata & -0.24 & -0.28 & -0.03 & 0.26 & -0.07 & -0.49 & -0.52 & -0.3 & -0.37 & -0.23 & -0.26 & 0.39 & -0.13 & -0.43 & 0.1 & 0.63 & 0.03 & -0.06 \\
\hline Lupinusdiehlii & -0.2 & -0.29 & -0.11 & -0.29 & 0.55 & 0.27 & -0.02 & 0.37 & 0.53 & 0.62 & 0.26 & -0.1 & -0.33 & 0.09 & 0.43 & -0.49 & -0.13 & -0.06 \\
\hline Cologaniaobovata & 0.28 & 0.71 & 0.09 & 0.03 & -0.57 & 0.15 & 0.51 & 0.07 & -0.42 & -0.54 & -0.03 & -0.27 & 0.5 & 0.43 & -0.47 & 0.01 & 0.01 & -0.3 \\
\hline Cologaniaangustifolia & 0.54 & 0.34 & 0.22 & -0.03 & -0.12 & 0.36 & 0.55 & 0.35 & -0.06 & -0.22 & 0.26 & -0.49 & 0.32 & 0.69 & -0.35 & -0.26 & 0.11 & -0.15 \\
\hline Chimaphilamaculata & -0.51 & -0.38 & -0.57 & -0.3 & -0.12 & -0.47 & -0.52 & -0.55 & -0.11 & -0.03 & 0.21 & 0.04 & -0.47 & -0.67 & 0.45 & 0.36 & -0.52 & -0.15 \\
\hline Oxalis spp. & 0.66 & 0.39 & 0.32 & 0.28 & -0.29 & 0.4 & 0.52 & 0.23 & -0.38 & -0.53 & 0.05 & -0.3 & 0.39 & 0.51 & -0.46 & 0.25 & 0.25 & -0.15 \\
\hline Geranium wislizeni & 0.25 & 0.21 & 0.56 & 0.66 & 0.2 & $\begin{array}{c}0.4 \\
-0.14\end{array}$ & 0.00 & 0.27 & $\begin{array}{l}-0.00 \\
-0.14\end{array}$ & $\begin{array}{l}-0.00 \\
-0.09\end{array}$ & -0.79 & 0.74 & 0.3 & -0.13 & $\begin{array}{l}-0.40 \\
-0.23\end{array}$ & 0.4 & 0.65 & 0.62 \\
\hline Commelinadianthifolia & 0.51 & 0.61 & 0.53 & 0.47 & -0.08 & 0.42 & 0.51 & 0.62 & -0.17 & -0.24 & -0.67 & 0.38 & 0.65 & 0.3 & -0.47 & 0.08 & 0.54 & 0.11 \\
\hline Acmisponwrightii & -0.27 & -0.45 & -0.23 & -0.4 & 0.69 & 0.24 & -0.02 & 0.35 & 0.82 & 0.84 & 0.39 & -0.1 & -0.58 & -0.06 & 0.57 & -0.53 & -0.23 & 0.01 \\
\hline Cyperussphaerolepis & 0.65 & 0.54 & 0.42 & 0.35 & -0.29 & 0.36 & 0.66 & 0.47 & -0.32 & -0.44 & -0.3 & -0.01 & 0.6 & 0.5 & -0.54 & 0.13 & 0.38 & -0.04 \\
\hline Pseudognaphaliumarizonicum & 0.49 & 0.45 & 0.4 & 0.24 & 0.21 & 0.34 & 0.62 & 0.56 & 0.23 & 0.13 & -0.37 & 0.32 & 0.17 & 0.34 & -0.19 & -0.11 & 0.39 & 0.35 \\
\hline Verbesinaparviflora & -0.58 & -0.32 & -0.65 & -0.37 & 0.05 & $\begin{array}{l}-0.69 \\
-0.69\end{array}$ & -0.52 & -0.57 & 0.00 & 0.15 & 0.13 & 0.24 & -0.65 & -0.79 & 0.62 & 0.28 & -0.58 & -0.13 \\
\hline $\begin{array}{l}\text { Penstemon miniatus var. } \\
\text { townsendianus }\end{array}$ & 0.39 & 0.59 & 0.00 & -0.12 & -0.21 & 0.06 & 0.33 & -0.12 & -0.16 & -0.25 & -0.1 & 0.03 & 0.15 & 0.15 & -0.19 & -0.23 & -0.03 & 0.11 \\
\hline Agastache pallida & -0.06 & -0.31 & -0.04 & -0.27 & 0.67 & 0.44 & 0.12 & 0.43 & 0.81 & 0.78 & 0.24 & -0.03 & -0.41 & 0.05 & 0.42 & -0.59 & -0.04 & 0.16 \\
\hline Packeracandidissima & 0.19 & 0.03 & 0.7 & 0.65 & 0.44 & 0.11 & 0.14 & 0.64 & 0.08 & 0.17 & -0.55 & 0.42 & 0.35 & 0.21 & -0.18 & 0.12 & 0.74 & 0.03 \\
\hline Milla biflora & 0.02 & -0.14 & -0.02 & -0.07 & $\begin{array}{l}-0.38 \\
-0.38\end{array}$ & -0.1 & -0.12 & $\begin{array}{l}-0.19 \\
-19\end{array}$ & -0.21 & -0.25 & 0.16 & -0.25 & 0.1 & 0.13 & -0.27 & -0.06 & -0.05 & 0.00 \\
\hline Ratibidamexicana & 0.42 & 0.24 & 0.6 & 0.53 & $\begin{array}{l}-0.00 \\
0.35\end{array}$ & $\begin{array}{l}-0.1 \\
0.25\end{array}$ & $\begin{array}{l}-0.12 \\
0.16\end{array}$ & $\begin{array}{l}-0.19 \\
0.44\end{array}$ & $\begin{array}{l}-0.12 \\
0.12\end{array}$ & $\begin{array}{l}-0.23 \\
0.11\end{array}$ & $\begin{array}{l}.10 \\
-0.76\end{array}$ & $\begin{array}{l}-0.25 \\
0.74\end{array}$ & $\begin{array}{l}0.1 \\
0.25\end{array}$ & $\begin{array}{l}.13 \\
0.04\end{array}$ & $\begin{array}{l}-0.27 \\
-0.19\end{array}$ & 0.05 & 0.66 & 0.66 \\
\hline Arctostaphylos pungens & -0.01 & -0.25 & 0.03 & 0.05 & -0.45 & -0.12 & -0.2 & -0.1 & -0.31 & -0.36 & 0.15 & -0.31 & 0.22 & 0.26 & -0.33 & 0.22 & -0.03 & -0.13 \\
\hline Ceanothus depressus & -0.37 & -0.53 & -0.32 & -0.5 & 0.69 & 0.26 & -0.13 & 0.19 & 0.82 & 0.9 & 0.41 & -0.09 & -0.64 & -0.13 & 0.68 & $\begin{array}{l}-0.67 \\
-0.67\end{array}$ & -0.32 & 0.06 \\
\hline Ceanothus coeruleus & -0.54 & -0.29 & -0.54 & -0.34 & -0.05 & -0.64 & -0.5 & -0.54 & -0.06 & 0.09 & 0.13 & 0.17 & -0.53 & -0.56 & 0.43 & 0.09 & -0.49 & -0.12 \\
\hline
\end{tabular}

Significant values after Bonferroni correction are marked in bold $(\alpha=0.0025)$, EC: Electric conductivity, P: Phosphorus (ppm), Ca: Calcium (ppm), Fe: Iron (ppm), K: Potassium (ppm), Mg: Magnesium (ppm), Mn: Manganese (ppm), Zn: Zinc (ppm), Cu: Copper (ppm), Sand (\%), Silt (\%), Sat: Water saturation (\%),OM: Organic material (\%), Clay (\%), \%K: Relative proportion of K in CEC (\%), \%Ca: Relative proportion of Ca in CEC (\%), \%Mg: Relative proportion of Mg in CEC (\%), \%Ca: Relative proportion of Ca in CEC (\%), CEC: Cation exchange capacity, HC: Hydraulic conductivity $(\mathrm{cm} / \mathrm{h})$.

The BLM regression model also showed that some soil variables were statistically significant predictors for explaining the species presence under the canopy or in the gaps (Table 4), given that the dependent variables yielded low $p$-Values. For the species not shown in Table 4, the model did not significantly predict occurrence.

Nevertheless, regarding which edaphic variables influenced the species presence, the model produced significant predictors (Tables 3 and 4). A positive correlation was found with the percent of water saturation (Sat) $\left(r=0.82 ; p \leq 2.87^{-6}\right)$, while for some species the correlation was moderate or low, e.g., in Ratibida mexicana and Agastache pallida, Sat was a significant predictor with respectively moderate correlation, r. Ratibida mexicana and Stevia serrata yielded the highest number of significant predictors (Tables 3 and 4).

The probability of presence of each species was modelled with moderate accuracy by different physical and chemical soil properties. The relationships between selected soil traits and the probability of each species are shown in Figure 3. For Sand and $\mathrm{Na}$, the fitted probability corresponds to the relationships between the two variables (blue line). Figure $3 a$ shows a negative relationship between the probability and the predictor variables (percent of water saturation, (Sat)): as the predictor increases, the probability decreases; Figure 3c shows a positive relationship. The difference or reduction between output deviances (ND and RD) indicated that the model is useful for predicting species presence. The best model fits were found for Viola grahamii and Agastache pallida, indicated by the lowest $p$ Values (Table 4). 
Table 4. Binomial logistic regression model coefficients for soil variables explaining the species presence under the canopy and in gaps.

\begin{tabular}{|c|c|c|c|c|c|c|c|c|}
\hline \multicolumn{2}{|l|}{ Species } & \multirow{2}{*}{$\begin{array}{c}\text { Estimate } \\
33.91\end{array}$} & \multirow{2}{*}{$\begin{array}{c}\text { Std. Error } \\
15.42\end{array}$} & \multirow{2}{*}{$\frac{p \text {-Value }}{* 0.03}$} & \multirow{2}{*}{$\frac{\text { ND }}{27.53}$} & \multirow{2}{*}{$\frac{\text { RD }}{11.29}$} & \multirow{2}{*}{$\begin{array}{l}\text { AIC } \\
19.29\end{array}$} & \multirow{2}{*}{$\begin{array}{l}\text { PoP } \\
0.98\end{array}$} \\
\hline Viola grahamii & Intercept & & & & & & & \\
\hline & Sand & -0.50 & 0.23 & $* 0.03$ & & & & \\
\hline & $\mathrm{Ca}$ & -0.01 & 0.00 & $* 0.03$ & & & & \\
\hline \multirow[t]{2}{*}{ Phaseolus paroulus } & Intercept & -2.01 & 1.55 & 0.19 & 25.90 & 22.05 & 26.05 & 0.65 \\
\hline & $\mathrm{Na}$ & 0.02 & 0.01 & 0.09 & & & & \\
\hline \multirow[t]{3}{*}{ Stevia serrata } & Intercept & 0.61 & 1.51 & 0.69 & 25.90 & 19.80 & 25.80 & 0.94 \\
\hline & $\mathrm{EC}$ & -20.78 & 11.49 & 0.07 & & & & \\
\hline & $\mathrm{Ca}$ & 0.00 & 0.00 & 0.06 & & & & \\
\hline \multirow[t]{2}{*}{ Lupinusdiehlii } & Intercept & -6.22 & 2.94 & $* 0.03$ & 22.49 & 16.38 & 20.38 & 0.99 \\
\hline & $\mathrm{K}^{1}$ & 0.01 & 0.01 & 0.05 & & & & \\
\hline \multirow[t]{3}{*}{ Chimaphilamaculata } & Intercept & -22.72 & 12.18 & 0.06 & 24.43 & 24.43 & 25.75 & 0.99 \\
\hline & Sand & 0.276 & 0.15 & 0.07 & & & & \\
\hline & Silt & 0.22 & 0.144 & 0.12 & & & & \\
\hline \multirow{2}{*}{$\begin{array}{l}\text { Oxalis metcalfei } \\
+O . \text { hernandezii }\end{array}$} & Intercept & -3.13 & 1.75 & $\cdot 0.07$ & 25.90 & 19.01 & 23.01 & 0.82 \\
\hline & EC & 17.57 & 8.23 & $* 0.03$ & & & & \\
\hline \multirow[t]{3}{*}{ Geranium wislizeni } & Intercept & 1.25 & 2.44 & 0.61 & 22.49 & 12.62 & 18.62 & 0.98 \\
\hline & $\mathrm{Fe}$ & -0.14 & 0.08 & 0.07 & & & & \\
\hline & $\mathrm{Cu}$ & 27.24 & 14.28 & 0.06 & & & & \\
\hline \multirow[t]{2}{*}{ Acmisponwrightii } & Intercept & -17.09 & 9.92 & 0.08 & 25.90 & 8.09 & 12.09 & 0.99 \\
\hline & Sat & 0.34 & 0.20 & 0.09 & & & & \\
\hline \multirow[t]{2}{*}{ Cyperus sphaerolepis } & Intercept & -4.64 & 2.72 & 0.09 & 20.02 & 12.31 & 16.31 & 0.81 \\
\hline & $\mathrm{Fe}$ & 0.08 & 0.04 & * 0.04 & & & & \\
\hline \multirow[t]{2}{*}{ Pseudognaphaliumarizonicum } & Intercept & -2.73 & 1.99 & 0.17 & 20.02 & 13.84 & 17.84 & 0.69 \\
\hline & EC & 21.65 & 11.51 & 0.06 & & & & \\
\hline \multirow{2}{*}{$\begin{array}{l}\text { Penstemon miniatus var. } \\
\text { townsendianus }\end{array}$} & Intercept & -2.97 & 1.21 & $* 0.01$ & 20.02 & 15.93 & 19.93 & 0.95 \\
\hline & $\mathrm{P}$ & 0.08 & 0.04 & 0.06 & & & & \\
\hline \multirow[t]{2}{*}{ Agastache pallida } & Intercept & -7.50 & 3.33 & * 0.02 & 26.92 & 15.24 & 19.24 & 0.99 \\
\hline & Sat & 0.15 & 0.07 & * 0.03 & & & & \\
\hline \multirow[t]{3}{*}{ Verbesinaparviflora } & Intercept & -0.16 & 2.18 & 0.94 & 26.92 & 19.67 & 25.67 & 0.99 \\
\hline & Sat & 0.07 & 0.04 & * 0.04 & & & & \\
\hline & $\mathrm{Fe}$ & -0.05 & 0.03 & 0.07 & & & & \\
\hline \multirow[t]{3}{*}{ Ratibidamexicana } & Intercept & 6.66 & 4.95 & 0.18 & 26.92 & 16.08 & 22.08 & 0.98 \\
\hline & Sat & 0.09 & 0.04 & $* 0.04$ & & & & \\
\hline & Sand & -0.21 & 0.10 & * 0.04 & & & & \\
\hline \multirow[t]{2}{*}{ Ceanothus depressus } & Intercept & 3.63 & 1.48 & * 0.01 & 26.92 & 10.28 & 14.27 & 1 \\
\hline & $\mathrm{P}$ & -0.25 & 0.14 & $\cdot 0.06$ & & & & \\
\hline \multirow[t]{3}{*}{ Ceanothus coeruleus } & Intercept & -31.54 & 15.29 & * 0.04 & 22.49 & 16.21 & 22.21 & 1 \\
\hline & Sand & 0.34 & 0.17 & $* 0.05$ & & & & \\
\hline & Silt & 0.37 & 0.19 & $\cdot 0.06$ & & & & \\
\hline
\end{tabular}

Sat: Water saturation (\%), Fe: iron (ppm), Ca: Calcium (ppm), Mg: magnesium (ppm), Zn: zinc (ppm), Na: sodium (ppm), Cu: copper (ppm), EC: electric conductivity (dS/m), P: phosphorus (ppm), pH: hydrogen ion concentration (numerical), K: potassium (ppm), H: relative proportion of $\mathrm{H}$ in CEC (\%). Significance level: $0.05(*), 0.10(\cdot)$, PoP: minimum probability, ND: Null deviation, RD: Residual deviation, AIC: Akaike information criterion. 
(a)

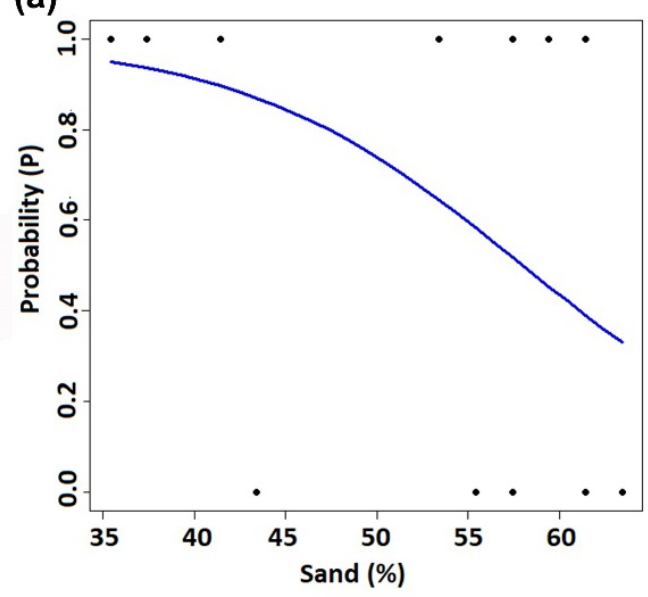

(c)

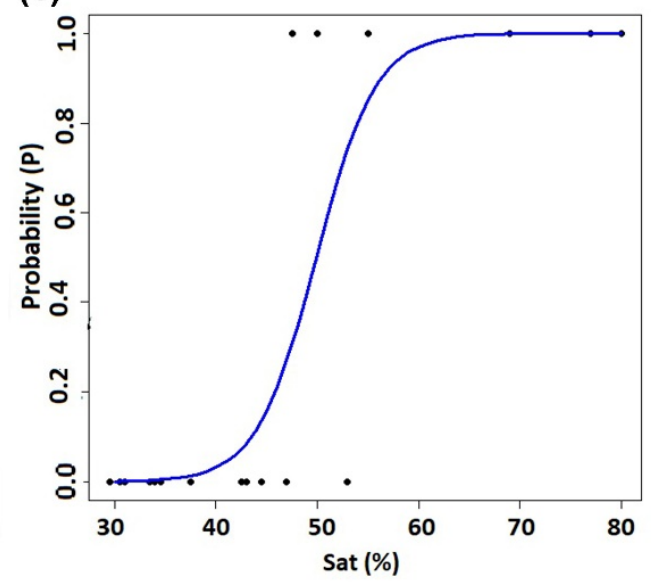

(e)

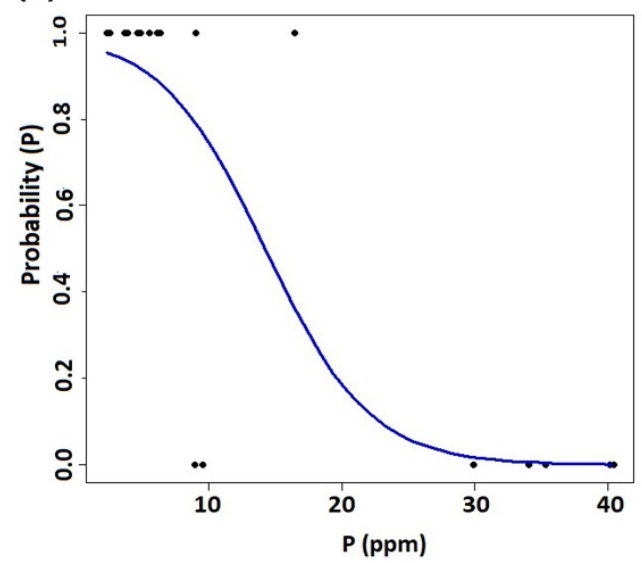

(b)

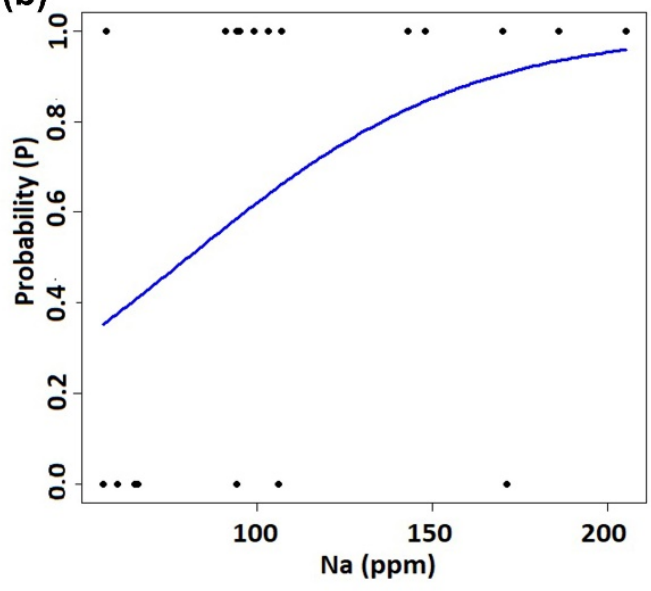

(d)

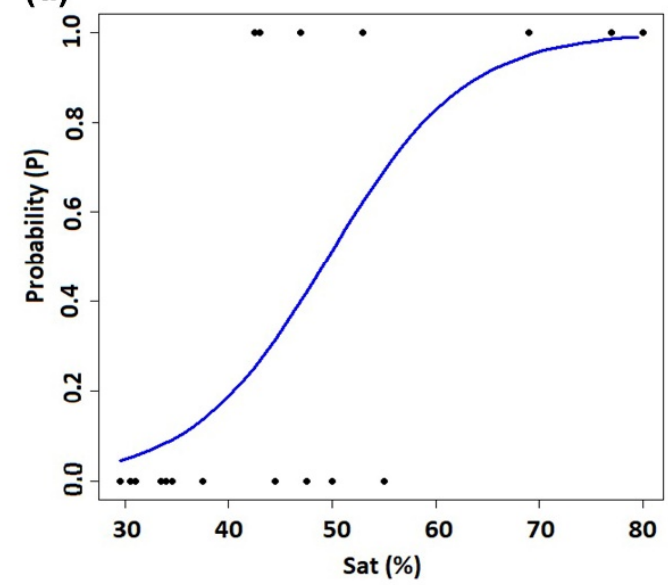

(f)

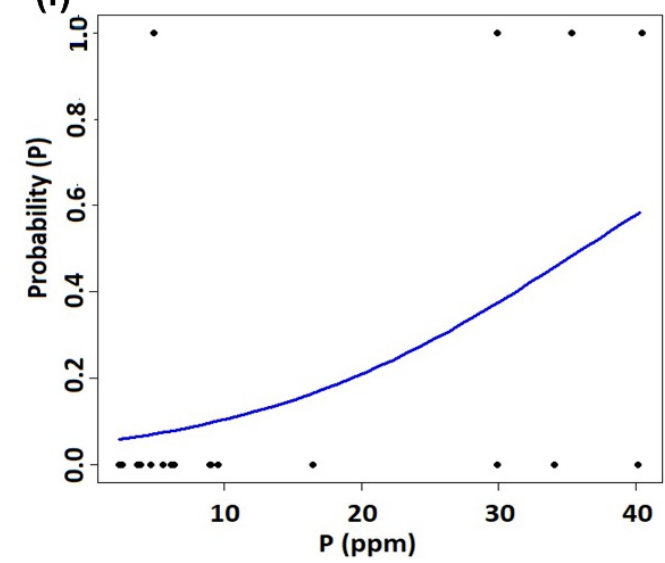

Figure 3. Probability $(\mathrm{P})$ of the presence of species in relation to soil components according to the $\operatorname{BLM}(p<0.05)$ : (a) Viola grahamii, (b) Phaseolus parvulus, (c) Acmispon wrightii, (d) Agastache pallida, (e) Ceanothus depressus, (f) Penstemon miniatus. P (phosphorus, ppm), Na (sodium, ppm), Sat (Water saturation, \%).

Predictions for scarcely represented species, such as Chimaphila maculata, may be biased due to the small sample size.

The RF model indicated that the most important soil traits in relation to the probability of the species were $\mathrm{Cu}, \mathrm{Ca}, \mathrm{K}, \mathrm{Fe}, \mathrm{Zn}, \mathrm{Mg}, \mathrm{P}, \mathrm{CEC}, \mathrm{OM}$, Clay, Silt, \%K and \%Mg, all of which had a large enough influence to appear in the RF models for different species (Figure 4 , Table S2). 

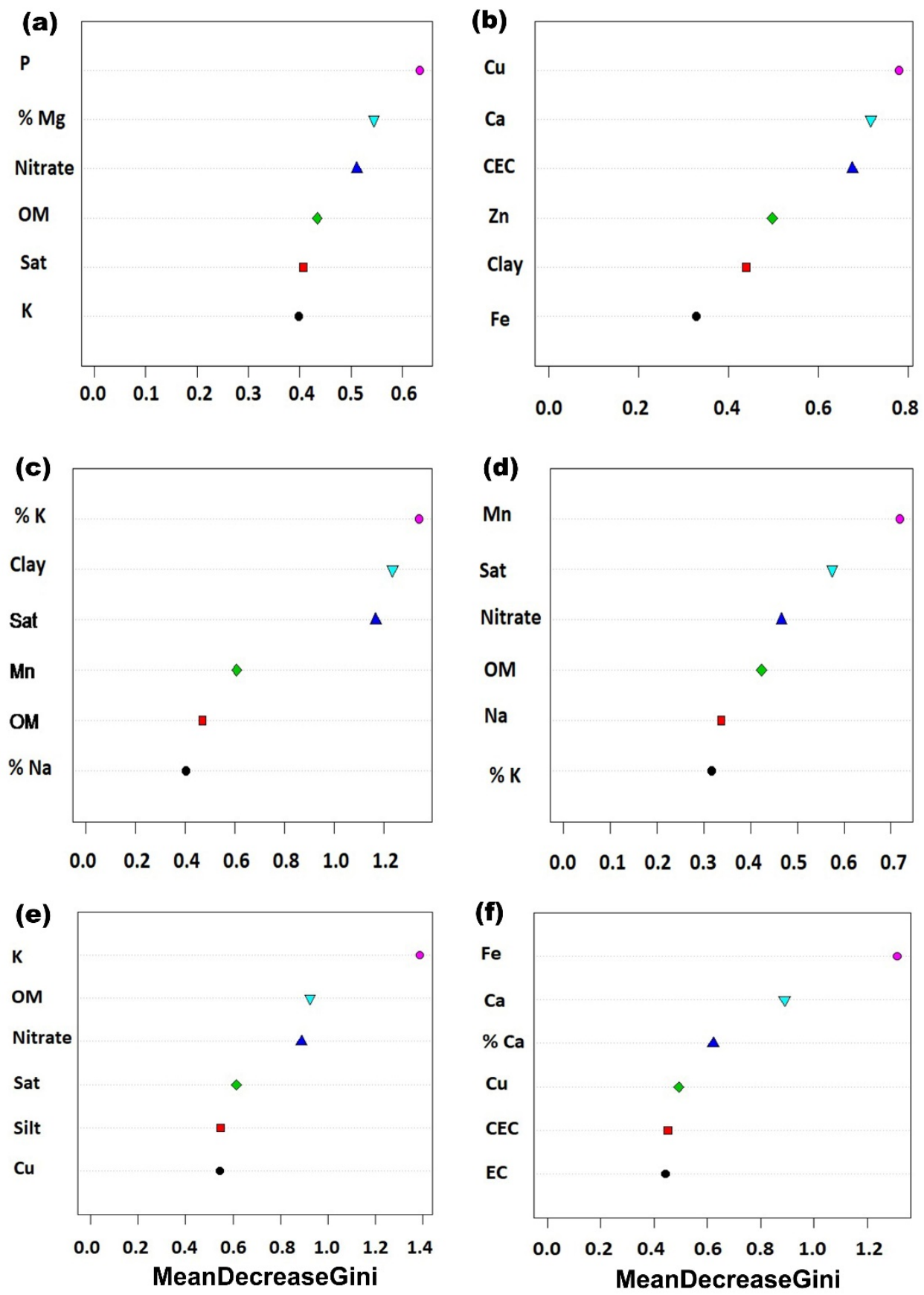

Figure 4. The six most important soil variables for the presence of species, detected by Random Forest are listed for presentation purposes. (a) Lupinus diehlii, (b) Commelina dianthifolia, (c) Acmispon wrightii, (d) Arctostaphylos pungens, (e) Agastache pallida (f) Ceanothus coeruleus. $\mathrm{NO}_{3}$ : Nitrate (kg/ha), P: Phosphorus (ppm), Ca: Calcium (ppm), Na: Sodium (ppm), K: Potassium (ppm), Fe: Iron (ppm), Mn: Manganese (ppm), Cu: Copper (ppm), OM: Organic matter (\%), Sat: Water saturation (\%), Silt (\%), Clay (\%), \%Ca: Relative proportion of Ca in CEC (\%), \%Mg: Relative proportion of Mg in CEC (\%), \%K: Relative proportion of $\mathrm{K}$ in CEC (\%), \%Na: Relative proportion of Na in CEC (\%), CEC: Cation exchange capacity, EC: EC: Electrical conductivity (dS/m). For more information about parameter units see Tables S1 and S2.

The RF models for Commelina dianthifolia, Acmispon wrightii and Ceanothus coeruleus performed best, according to moderate TSS, with values of $0.93,0.73$ and 0.73 , respectively (Table 5, Figure $4 b, c, f)$. A low error rate (OBB) indicates a strong classifier, related to the lowest values of the number of randomly chosen variables. For the best performance of the 
predictor, the sensitivity of the RF presence-absence models was generally high, but the specificity was low to moderate.

Table 5. Quality index of the Random Forest models of species presence with soil variables.

\begin{tabular}{cccccc}
\hline Species & ROC & Sens & Spec & TSS & OOB (\%) \\
\hline Lupinusdiehlii & 0.60 & 0.87 & 0.40 & 0.27 & 20 \\
Commelinadianthifolia & 1.00 & 1.00 & 0.93 & 0.93 & 5 \\
Acmisponwrightii & 0.93 & 0.93 & 0.80 & 0.73 & 10 \\
Agastache pallida & 0.85 & 0.80 & 0.50 & 0.30 & 10 \\
Ceanothus coeruleus & 0.87 & 0.93 & 0.80 & 0.73 & 15 \\
Arctostaphylos pungens & 0.79 & 0.87 & 0.25 & 0.12 & 15 \\
\hline
\end{tabular}

ROC: receiver operating characteristic, Sens: sensitivity, Spec: specificity, TSS: True skill statistic, OOB: out of bag error or mean prediction error.

\section{Discussion}

\subsection{Relationships between the Presence of Understory Species and Soil Variables}

The study findings revealed that several soil variables have a significant influence on understorey species. The relationships between soil characteristics and floristic composition, richness and distribution of understorey plants in temperate forests have been described in several studies $[9,14,61,62]$. In the present study, the occurrence of the understorey species appeared to be more closely related to the soil conditions than to the influence of canopy or gaps. A relationship between some edaphic components and properties (e.g., Mg, Ca, P, Zn, Cu, Mn, Fe, Mg, Na, K, Zn, \%K, \%Mg, OM, Sat, Sand, Silt, and $\mathrm{CEC}$ ) and the presence of certain understorey species was detected by both models (BLM and RF) (Tables 4 and 5; Figures 3 and 4).

Soil $\mathrm{pH}$ is often recognized as having a strong influence on vegetation (e.g., [63]; $A$. pungens and $C$. coeruleus are shrubs related to $\mathrm{pH}$ (Table S2). However, we did not find a significant association between $\mathrm{pH}$ and the occurrence of the other species, which may be explained by the scarce $\mathrm{pH}$ differences among the studied sites, all of which are moderately acidic (Table S1). A forest with slightly acidic to neutral soil ( $\mathrm{pH}$ 6.2-7) in the Sierra Madre Oriental, northeastern Mexico, has a high richness of shrub species [64]; however, this is related to the floristic affinities with chaparral and xerophytic scrub from lower elevations, rather than to $\mathrm{pH}$.

The nitrate content in the soil varied widely in the study area, ranging from $9.73 \mathrm{~kg} \mathrm{ha}^{-1}$ to $68.99 \mathrm{~kg} \mathrm{ha}^{-1}$. Understorey plants are generally important in the nitrogen deposition process in forests [65]; the essential concentrations in forest ecosystems are realized by plants, incorporate available nitrogen released by microbial decomposition into carbon compounds that are difficult to decompose [66]. The presence of Lupinus diehlii, Agastache pallida, Arctostaphylos pungens, and Ceanothus coeruleus in the area appears to be related to nitrate content, according to the RF model. Species of Ceanothus are among the major actinorhizal plants in the world, fixing nitrogen through actinomycetes of the genus Frankia in their roots, as does Alnus [67,68]. Legumes (Fabaceae) are well-known nitrogen fixers that act through symbiotic bacteria in their root nodules; one species of Lupinus has been recorded as a particularly efficient fixer of atmospheric N [69]. Although no significant relation between the nitrate content and the presence of legumes was found in this study, the relationship with soil fertility is worth investigating in this region, given their abundance, e.g., Cologania obovata, C. angustifolia, Phaseolus pauciflorus, and Lupinus spp., among others.

The effect of forest management on soil nitrification and its relationship with forest species was not considered here; however, our findings are consistent with those of Dominguez-Guerrero et al. [48], who recorded an even broader range of soil nitrate content in a study determining the habitat of Picea chihuahuana across the Sierra Madre Occidental. Otherwise, nitrate concentrations have been attributed to air pollution and disturbances caused by forest harvesting in temperate forests in Europe and North America [70] and in Mexican mountain pine (Pinus hartwegii) forests [71]. 
The influence of factors such as livestock farming, logging and other human activities on the herbaceous community was not considered. However, visual evidence indicates that some species (e.g., Penstemon miniatus, Agastache pallida) occur in areas impacted by logging, while others (Ceanothus spp., Arctostaphylos pungens, and Ratibida mexicana) prosper in areas affected by other types of degradation, although with similar soil affinities (e.g., low organic matter and sandy loam soils). These species have been associated with deteriorated areas of temperate forests $[40,72]$. The impact of anthropogenic activities on forest species, decreasing or enhancing their presence and distribution, has been widely recorded [73-75], but it has not yet been explored in this region.

The study findings show that the occurrence of most understory species considered appears to be linked to soil properties (Tables 3 and 4). Previous findings also indicate that understorey species are governed by different factors other than those affecting the overstorey $[9,19]$. Understorey species richness, mainly determined by soil conditions, and canopy richness, which is correlated with climate, are attributable to differences in the life-form and life strategy of the plants in the upper and lower strata of forests [61].

\subsection{Relationships between Presence of Understorey Species, Forest Canopy and Gaps}

Most of the herb and shrub species considered were found both under the canopy and in exposed areas, and no significant differences were found in regard to their preference for one or another type of area. Nevertheless, frequency data indicate some trends (Tables 2 and 4, Figure 4). The lack of clear preferences of the understorey species for growing either in openings or under the canopy can be partly explained by the intrinsic biological attributes of some of the local species. For example, of those species with the highest occurrence values that develop both in gaps and below the canopy, two are generalists with a broad ecological and geographical distribution (Cologania obovata and Stevia serrata) [72], and one (Packera candidissima) is a regional endemic to the northern zone of the Sierra Madre Occidental [76], although abundant and with a high adaptation capability favoured by its colonial habit. The data presented here regarding the correlation with canopy and gaps are based on occurrences (presence/absence), and different results may be obtained when density or other quantitative data are considered.

Another explanation for the low proportion of plants restricted to growing either in gaps or under the canopy may be the relative openness of the forests from the northern Sierra Madre Occidental [40]. In this region, tree density is low, ranging from 383 to 1573 trees per hectare in the Colonia Nicolás Bravo 2 and the Ejido Socorro Rivera, respectively [28] and even in the latter case the canopy cannot be considered closed. Humidity, rather than light, is the main limiting factor in those areas, together with the effects of extreme drought and frosts, which are common in the zone [28]. The low density may also affect soil water availability, as direct radiation and high evapotranspiration affect the understorey composition [77], in contrast to what occurs in dense forests, where light is the main limiting factor and the cover and richness of herbs increase in the gap openings [78-80], favouring colonization; gap size also influences the presence of some species [81,82]. Species composition can increase around the tree canopy, favoured by environmental edaphic variables and the availability of water in the soil [81-83], as also occurs for regeneration in the study area [28]. Soil conditions influence the herbaceous layer under the forest canopy $[79,84,85]$ and, as already mentioned, the soil properties and the broad ecological adaptation of many species in the study area may have a stronger influence on the local distribution of understorey plants.

Although canopy provides some protection in the study area, it is not as essential as in denser forests. Shelter from the canopy is helpful to conserve humidity for water claiming species, as recorded by Tang et al. [86], or to mitigate extremely high temperatures [87], but does not explain the preference of the few species that appeared most frequently under the canopy in the present study. Humidity is not a particularly limiting factor for the most common, well-adapted herbaceous species in the region, as most precipitation falls during a short season (Southwest monsoon or Mexican monsoon) [88], during which heavy 
rains provide plants with more water than needed. During the dry, cold season, most of the plants are dormant and the canopy shade/protection is therefore not as necessary as in drier areas. These hypotheses remain to be explored for the understorey species in the region.

Nevertheless, occurrence data indicate that canopy may be an important, favourable factor for a few of the studied species. Of the 12 most frequent species, five grow almost equally in gaps and below the canopy, five show a preference for gaps and two were more frequent under the canopy. Penstemon miniatus is found under P. engelmannii, P. arizonica and P. leiophylla, mainly occupying areas with low organic matter and sandy soils. These findings are consistent with those of Villers et al. [89], who recorded Penstemon sp. in closed and semi-closed canopy of a Pinus forest, although other species of Penstemon prefer open areas. Among the shrubs, Ceanothus depressus was more frequent under the canopy of Quercus spp., Pinus arizonica and P. strobiformis. Ceanothus is a widely distributed genus in North America, being common in pine and oak forests [90]. Ceanothus depressus is endemic to the Sierra Madre Occidental, and its preference for shaded sites may be associated with the aforementioned symbiosis with actinomycetes and nitrogen fixation $[67,68]$. The relationship between the abundant $C$. depressus with the nitrogen deposition and the fertility of the forest soils would be worth exploring in the study region.

Several of the understorey species in the area are heliophytes, which can colonize open areas due to their fast-growth rates and good dispersal capacity [91-94]. The more frequent species in open areas include Agastache pallida, Commelina dianthifolia, Cyperus sphaerolepis, Geranium wislizeni, Pseudognaphalium arizonicum, Ratibida mexicana, Milla biflora and Arctostaphylos pungens (Table 2). All of these species belong to very well represented and widely distributed taxonomic groups in Mexico [91-94], and they can therefore be considered well adapted plants capable of growing under different conditions.

The understorey of temperate forests contains the highest floristic diversity in Mexico (about 7000 species, including trees) [36]. This, along with the role of the understorey cover in maintaining forest structure and function, highlights the value of the understorey and the importance of considering it in forest management plans.

\section{Conclusions}

In the study area, understorey species are more strongly influenced by physical and chemical soil properties than by their location under canopy or in gaps. The low correlation between species occurrence and the forest canopy or gaps can be partly explained by the relatively open canopy in the forests under study. The results highlight the usefulness of soil variables for local scale modelling, in order to determine which edaphic elements influence the presence of understorey species. This study contributes to a better understanding of the ecological factors that regulate the composition and local distribution of understorey plants in the Sierra Madre Occidental. The findings may also serve as a basis for further research on combining environmental and management data with species composition. Many other aspects of the forest understorey remain to be explored in the study region, e.g., the relationship between nitrogen fixing plants and soil fertility, the influence of grazing and the importance of understorey species in soil retention. Also, a better knowledge of how human activities influence the forest would provide useful information to enhance its management. The application of other models, such as Generalized Linear Mixed Model (GLMM) may help to understand better the complex relationships of the species and the environment. Such information could be used to improve environmentally sound forest management practices.

Supplementary Materials: The following are available online at https:/ / www.mdpi.com/article/10 .3390/f12091198/s1, Table S1: Descriptive statistics for the soil variables analyzed; Table S2: Edaphic variables of greater relative importance for the presence of each species, according to variable selection by Random Forest. 
Author Contributions: Conceptualization, C.W.; Data curation, J.F.M.-N. and C.W.; Formal analysis, J.F.M.-N., M.S.G.-E. and C.W.; Investigation, J.F.M.-N., M.S.G.-E., J.C.H.-D., C.A.L.-S. and C.W.; Methodology, J.F.M.-N. and C.W.; Resources, C.W.; Supervision, M.S.G.-E. and C.W.; Validation, J.F.M.-N., J.C.H.-D. and C.W.; Visualization, J.F.M.-N. and C.W.; Writing-original draft, J.F.M.-N., C.W. and M.S.G.-E.; Writing-review \& editing, J.F.M.-N., M.S.G.-E., J.C.H.-D., C.A.L.-S., C.E.B.-S., A.C.-P. and C.W. All authors have read and agreed to the published version of the manuscript.

Funding: This work was supported by a grant of the National Council of Science and Technology (CONACyT) of Mexico to J.F.M.-N. (270019). The financiers had no influence on the design of the study, collection and analysis of the data nor the preparation and publication of the manuscript.

Institutional Review Board Statement: Not applicable.

Informed Consent Statement: Not applicable.

Data Availability Statement: Not applicable.

Acknowledgments: We appreciate the careful review of the manuscript and the valuable comments provided by two anonymous reviewers. Our sincere thanks to Ing. Santos Gregorio Rodríguez García, of the ejido El Largo y Anexos and the Regional Forest Management Unit (UMAFOR 0802) from Madera, Chihuahua for the information provided. We also thank Ing. Royce David Bustillos for his valuable support in locating the sampling sites.

Conflicts of Interest: The authors declare no conflict of interest. The funders had no role in the design of the study; in the collection, analyses, or interpretation of data; in the writing of the manuscript, or in the decision to publish the results.

\section{References}

1. Leathwick, J.R.; Austin, M.P. Competitive interactions between tree species in New Zealand's old-growth indigenous forests. Ecology 2001, 82, 2560-2573. [CrossRef]

2. Graham, C.H.; Ferrier, S.; Huettman, F.; Moritz, C.; Peterson, A.T. New developments in museum-based informatics and applications in biodiversity analysis. Trends Ecol. Evol. 2004, 19, 497-503. [CrossRef]

3. Diekmann, M.; Michaelis, J.; Pannek, A. Know your limits-The need for better data on species responses to soil variables. Basic Appl. Ecol. 2015, 16, 563-572. [CrossRef]

4. Chaulagain, S.; Shrestha-Malla, A.M. Effects of Edaphic (Soil) Factors on Plant Distribution in Chameli Community Forest, Bhaktapur, Nepal. Int. J. Appl. Sci. Biotech. 2018, 6, 27-37. [CrossRef]

5. Gaitán, J.J.; López, R.C.; Bran, D.E. Vegetation composition and its relationship with the environment in mallines of north Patgagonia, Argentina. Wetlands Ecol. Manag. 2011, 19, 121-130. [CrossRef]

6. Verberk, W. Explaining general patterns in species abundance and distributions. Nat. Educ. Knowl. 2011, 3, 38.

7. Silva-Flores, R.; Pérez-Verdín, G.; Wehenkel, C. Patterns of tree species diversity in relation to climatic factors on the Sierra Madre Occidental, Mexico. PLoS ONE 2014, 9, e105034. [CrossRef] [PubMed]

8. Kosanic, A.; Anderson, K.; Harrison, S.; Turkington, T.; Bennie, J. Changes in the geographical distribution of plant species and climatic variables on the West Cornwall peninsula (South West UK). PLoS ONE 2018, 13, e0191021. [CrossRef]

9. Walthert, L.; Meier, E.S. Tree species distribution in temperate forests is more influenced by soil than by climate. Ecol. Evol. 2017, 7, 9473-9484. [CrossRef]

10. Yousaf, A.; Shabbir, R.; Jabeen, A.; Erum, S.; Ahmad, S.S. Linkage between herbaceous vegetation and soil characteristics along rawal dam islamabad. J. Soil Sci. Plant Nutr. 2016, 16, 88-100. [CrossRef]

11. Germany, M.S.; Bruelheide, H.; Erfmeier, A. Limited tree richness effects on herb layer composition, richness and productivity in experimental forest stands. J. Plant Ecol. 2017, 10, 190-200. [CrossRef]

12. Magnago, L.F.S.; Rocha, M.F.; Meyer, L.; Martins, S.V.; Meira-Neto, J.A.A. Microclimatic conditions at forest edges have significant impacts on vegetation structure in large Atlantic Forest fragments. Biodiversity Conserv. 2015, 24, 2305-2318. [CrossRef]

13. Bátori ZLengyel, A.; Maróti, M.; Körmöczi, L.; Tölgyesi, C.; Bíró, A.; Tóth, M.; Kincses, Z.; Cseh, V.; Erdős, L. Microclimatevegetation relationships in natural habitat islands: Species preservation and conservation perspectives. Időjárás/Q. J. Hung. Meteorol. Serv. 2014, 118, 257-281.

14. Hart, S.A.; Chen, H.Y.H. Understory vegetation dynamics of North American Boreal Forest. Crit. Rev. Plant Sci. 2006, 25, 381-397. [CrossRef]

15. Eysenrode Salvador-Van, D.; Kockelbergh, F.; Bogaert, J.; Impens, I.; Van Hecke, P. Determinación del borde de la brecha del dosel y la importancia de los bordes de la brecha para la diversidad de plantas. Web Ecol. 2002, 3, 1-5. [CrossRef]

16. Chen, J.; Saunders, S.C.; Crow, T.R.; Naiman, R.J.; Brosofske, K.D.; Mroz, G.D.; Brookshire, B.L.; Franklin, J.F. Microclimate in forest ecosystem and landscape ecology: Variations in local climate can be used to monitor and compare the effects of different management regimes. BioScience 1999, 49, 288-297. [CrossRef] 
17. Hemrová, L.; Knappová, J.; Münzbergová, Z. Assessment of habitat suitability is affected by plant-soil feedback: Comparison of field and garden experiment. PLOS ONE 2016, 11, e0157800. [CrossRef] [PubMed]

18. Arámbula-Salazar, J.A.; Ibarra-Salinas, B.I.; González-Laredo, R.F.; Muñoz-Galindo, O.D.; Hernández-Vela, H. Variación estacional de compuestos fenólicos foliares en Quercus sideroxyla en diferentes tipos de suelo. Madera Bosques 2010, 16, 49-59. [CrossRef]

19. Gilliam, F.S. The ecological significance of the herbaceous layer in temperate forest ecosystems. BioScience 2007, 57, 845-858. [CrossRef]

20. Gilliam, F.S.; Turrill, N.L.; Adams, M.B. Herbaceous-layer and overstory species in clear-cut and mature central Appalachian hardwood forests. Ecol. Appl. 1995, 5, 947-955. [CrossRef]

21. Bartels, S.F.; Chen, H.Y.H. Is understory plant species diversity driven by resource quantity or resource heterogeneity? Ecology 2010, 91, 1931-1938. [CrossRef]

22. Nearing, M.A.; Jetten, V.; Baffaut, C.; Cerdan, O.; Couturier, A.; Hernández, M.; Le, B.Y.; Nichols, M.H.; Nunes, J.P.; Renschler, C.S.; et al. Modeling response of soil erosion and runoff to changes in precipitation and cover. Catena 2005, 61, 131-154. [CrossRef]

23. Durán, Z.V.H.; Rodríguez, P.C.R. Soil-erosion and runoff prevention by plant covers. A review. Agron. Sustain. Dev. 2008, 28, 65-86. [CrossRef]

24. Goebes, P.; Schmidt, K.; Seitz, S.; Both, S.; Bruelheide, H.; Erfmeier, A.; Scholten, T.; Kühn, P. The strength of soil-plant interactions under forest is related to a Critical Soil Depth. Sci. Rep. 2019, 9, 8635. [CrossRef] [PubMed]

25. Cruz-Cobos, F.; Monárrez-González, J.C.; Tecla, A.; Perez-Verdin, G.; Wehenkel, C. Effects of stand variables on stemflow and surface runoff in pine-oak forests in northern Mexico. PLoS ONE 2020, 15, e0235320. [CrossRef]

26. Narváez, R. Suelo-calidad de estación en el área experimental forestal madera, chihuahua. Rev. Mex. Cienc. For. 2021, 17, 3-26.

27. Alfaro, R.T.; Martínez-Vilalta, J.; Retana, J. Regeneration patterns in Mexican pine-oak forests. For. Ecosyst. 2019, 6, 50. [CrossRef]

28. Maciel-Nájera, J.F.; Hernández-Velasco, J.; González-Elizondo, M.S.; Hernández-Díaz, J.C.; López-Sánchez, C.A.; Antúnez, P.; Bailón-Soto, C.E.; Wehenkel, C. Unexpected spatial patterns of natural regeneration in typical uneven-aged mixed pine-oak forests in the Sierra Madre Occidental, Mexico. Global Ecol. Conserv. 2020, 23, e01074. [CrossRef]

29. Monarrez-Gonzalez, J.C.; Perez-Verdin, G.; Gonzalez-Elizondo, M.S.; Marquez-Linares, M.A.; Gutierrez-Yurrita, P.J. Effect of forest management on tree diversity in temperate ecosystem forests in northern Mexico. PLoS ONE 2020, 15, e0233292. [CrossRef] [PubMed]

30. Galicia, L.; Potvin, C.; Messier, C. Maintaining the high diversity of pine and oak species in Mexican temperate forests: A new management approach combining functional zoning and ecosystem adaptability. Can. J. For. Res. 2015, 45, 1358-1368. [CrossRef]

31. Arriaga, L.; Mercado, C. Seed bank dynamics and tree-fall gaps in a northwestern Mexican Quercus-Pinus forest. J. Veg. Sci. 2004, 15, 661-668. [CrossRef]

32. Graciano-Ávila, G.; Alanís-Rodríguez, E.; Aguirre-Calderón, Ó.A.; González-Tagle, M.A.; Treviño-Garza, E.J.; Mora-Olivo, A. Caracterización estructural del arbolado en un ejido forestal del noroeste de México. Madera Bosques 2017, 23, 137-146. [CrossRef]

33. López-Hernández, J.A.; Aguirre-Calderón, Ó.A.; Alanís-Rodríguez, E.; Monarrez-Gonzalez, J.C.; González-Tagle, M.A.; JiménezPérez, J. Composición y diversidad de especies forestales en bosques templados de Puebla, México. Madera Bosques 2017, 23, 39-51. [CrossRef]

34. Barbier, S.; Gosselin, F.; Balandier, P. Influence of tree species on understory vegetation diversity and mechanisms involved-A critical review for temperate and boreal forests. For. Ecol. Manag. 2008, 254, 1-15. [CrossRef]

35. Romero-Sanchez, M.E.; Perez-Miranda, R.; Gonzalez-Hernandez, A.; Velasco-Garcia, M.V.; Velasco-Bautista, E.; Flores, A. Current and Potential Spatial Distribution of Six Endangered Pine Species of Mexico: Towards a Conservation Strategy. Forests 2018, 9 , 767. [CrossRef]

36. Rzedowski, J. (Ed.) Vegetación de México; Limusa: México City, México, 1978; p. 432.

37. Granados-Sánchez, D.; López-Ríos, G.F.; Hernández-García, M.A. Ecología y silvicultura en bosques templados. Rev. Chapingo Ser. Cienc. For. Ambient. 2007, 13, 67-83.

38. Comisión Nacional para el Conocimiento y Uso de la Biodiversidad (CONABIO). Available online: https://www.biodiversidad. gob.mx/ecosistemas/bosqueTemplado.html (accessed on 3 November 2019).

39. World Wildlife Fund. Southern North America: Western Mexico into the Southwestern United States. 2021. Available online: https:/ / www.worldwildlife.org/ecoregions/na0302 (accessed on 23 July 2021).

40. González-Elizondo, M.S.; González-Elizondo, M.; Tena-Flores, J.A.; Ruacho-González, L.; López-Enríquez, I.L. Vegetación de la Sierra Madre Occidental, México: Una síntesis. Acta Bot. Mex. 2012, 100, 351-403. [CrossRef]

41. Mittermeier, R.A.; Turner, W.R.; Larsen, F.W.; Brooks, T.M.; Gascon, C. Global Biodiversity Conservation: The Critical Role of Hotspots; Zachos, F.E., Habel, J.C., Eds.; Biodiversity Hotspots; Springer Publishers: London, UK, 2011; pp. 3-22.

42. Guízar, E.; Benítez, A.; Bravo, O. La vegetación de la unidad de conservación y desarrollo forestal No. 2 "El Largo-Madera", Chihuahua. In Reporte; División de Ciencias Forestales, Universidad Autónoma de Chapingo: Chapingo, Mexico, 1992; 23p.

43. Instituto Nacional de Estadística, Geografía e Informática (INEGI). Carta de Uso de Suelo y Vegetación H12-9, 2016, Esc. 1:250 000, Serie V; Conjunto de datos vectoriales: Madera, CA, USA; Chihuahua, Mexico, 2016.

44. Wehenkel, C. Establecimiento de Sitios Permanentes de Investigación Forestal, de Suelos y Clima en la UMAFOR No. 0802, El Largo-Madera. In Informe Técnico; Comisión Nacional Forestal: Zapopan, Mexico, 2016.

45. ESRI. ArcGIS. for Desktop: Release 10.1 Esri, In Science + Business; Media B.V: Redlands, CA, USA, 2012. 
46. Thiers, B. Index Herbariorum: A Global Directory of Public Herbaria an Associated Staff. New York Botanical Garden's Virtual Herbarium, 2015. Available online: http:/ / sweetgum.nybg.org/ih/ (accessed on 2 April 2020).

47. Morett-Sánchez, J.C.; Cosío-Ruiz, C. Panorama de los ejidos y comunidades agrarias en México. Agric. Soc. Desarro. 2017, 14, 125-152. [CrossRef]

48. Dominguez-Guerrero, I.K.; Mariscal-Lucero, S.R.; Hernández-Díaz, J.C.; Heinze, B.; Prieto-Ruiz, J.A.; Wehenkel, C. Discrimination of Picea chihuahuana Martinez populations on the basis of climatic, edaphic, dendrometric, genetic and population traits. PeerJ 2017, 5, e3452. [CrossRef]

49. Hosmer, D.W.; Lemeshow, S.; Sturdivant, R.X. Applied Logistic Regression, 3rd ed.; Shewhart, W.A., Wilks, S.S., Eds.; John Wiley \& Sons: Hoboken, NJ, USA, 2013; Volume 398.

50. Field, A.; Miles, J.; Field, Z. Discovering Statistics Using R, 1st ed.; Sage Publications Ltd.: Southend Oaks, CA, USA, 2012.

51. Nordberg, L. Asymptotic normality of maximum likelihood estimators based on independent, unequally distributed observations in exponential family models. Scand. J. Statist. 1980, 7, 27-32.

52. Bangdiwala, S.I. Regression: Binary logistic. Int. J. Inj. Contr. and Saf. Promot. 2018, 25, 336-338. [CrossRef] [PubMed]

53. Fielding, A.H.; Bell, J.F. A review of methods for the assessment of prediction errors in conservation presence/absence models. Environ. Conserv. 1997, 24, 38-49. [CrossRef]

54. Breiman, L. Random forests. Mach. Learn. 2001, 45, 5-32. [CrossRef]

55. Hao, Z.; Du, J.; Nie, B.; Yu, F.; Xiong, W. Random Forest regression Based on Partial Least Squares. Connect Partial Least Squares and Random Forest. In Proceedings of the International Conference on Artificial Intelligence: Technologies and Applications (ICAITA 2016); Atlantis Press: Paris, France, 2016; pp. 191-196.

56. Tobias, R.D. An introduction to partial least squares regression. In Proceedings of the Twentieth Anmual SAS Users Group International Conference; SAS Institute Inc.: Cary, NC, USA, 1995; p. 20.

57. Ng, K.S.; A Simple Explanation of Partial Least Squares. The Australian National University, Canberra. 2013. Available online: http:/ / users.cecs.anu.edu.au/ \{\}kee/pls.pdf (accessed on 6 June 2020).

58. Allouche, O.; Tsoar, A.; Kadmon, R. Assessing the accuracy of species distribution models: Prevalence, kappa and the true skill statistic (TSS). J. Appl. Ecol. 2006, 43, 1223-1232. [CrossRef]

59. Venables, W.N.; Ripley, B.D. Modern Applied Statistics with S, 4th ed.; Springer Science + Business Media: New York, NY, USA, 2002; 498p.

60. R Core Team. R: A Language and Environment for Statistical Computing; R Foundation for Statistical Computing: Vienna, Austria, 2020.

61. Zhang, Y.; Chen, H.Y.H.; Taylor, A. Multiple drivers of plant diversity in forest ecosystems. Glob. Ecol. Biogeogr. 2014, 23, 885-893. [CrossRef]

62. Finzi, A.C.; Canham, C.D.; Van Bremeen, N. Canopy tree-soilinteractions whitin temperate forest: Species effects on pH and cations. Ecol. Appl. 1998, 8, 447-454.

63. Falkengren-Grerup, U. Soil Acidification and Its Impact on Ground Vegetation. Ambio 1989, 18, 179-183. [CrossRef]

64. Encina-Domínguez, J.A.; Arévalo, S.J.R.; Estrada-Castillon, E.; Mellado, B.M. Environmental and soil variables affecting the structure and floristic woody composition of oak forests of northeastern Mexico. Turk. J. Agric. For. 2018, 42, 262-271. [CrossRef]

65. Buriánek, V.; Novotný, R.; Hellebrandová, K.; Šrámek, V. Ground vegetation as an important factor in the biodiversity of forest ecosystems and its evaluation in regard to nitrogen deposition. J. For. Sci. 2013, 59, 238-252. [CrossRef]

66. Aber, J.; McDowell, W.; Nadelhoffer, K.; Magil, A.; Berntson, G.; Kamakea, M.; McNulty, S.; Currie, W.; Rustad, L.; Fernandez, I. Nitrogen Saturation in Temperate Forest Ecosystems, Hypotheses revisited. BioScience 1998, 48, 921-934. [CrossRef]

67. Santi, C.; Bogusz, D.; Franche, C. Biological nitrogen fixation in non-legume plants. Ann. Bot. 2013, 111, 743-767. [CrossRef]

68. Weil, R.R.; Brady, N.C. Nitrogen and Sulfur Economy of Soils. In The Nature and Properties of Soils; Weil, R.R., Brady, N.C., Eds.; Pearson: Columbus, OH, USA, 2017; pp. 584-642. [CrossRef]

69. Zamora, N.J.F.; Zapata, H.I.; Villalvazo, H.A. Fijación biológica del nitrógeno en tres especies silvestres del género Lupinus (Leguminosae, Papilionoideae) en México. Acta Bot. Mex. 2019, 126, e1543. [CrossRef]

70. Gundersen, P.; Schmidt, I.K.; Raulund-Rasmussen, K. Leaching of nitrate from temperate forests-Effects of air pollution and forest management. Environ. Rev. 2006, 14, 1-57. [CrossRef]

71. Fenn, M.E.; Geiser, L.H. Temperate sierras. In Assessment of Nitrogen Deposition Effects and Empirical Critical Loads of Nitrogen for Ecoregions of the United States; Pardo, L.H., Robin-Abbott, M.J., Driscoll, C.T., Eds.; Gen. Tech. Rep. NRS-80; US Department of Agriculture, Forest Service, Northern Research Station: Newtown Square, PA, USA, 2011; Volume 80, pp. 175-180.

72. Calderón de Rzedowski, G.; Rzedowski, J. Flora Fanerogámica del Valle de México, 2nd ed.; Instituto de Ecología, A.C. y Comisión Nacional para el Conocimiento y Uso de la Biodiversidad: Pátzcuaro, Michoacán, Mexico, 2005; p. 1406.

73. Zheng, J.G.; Chen, Y.W.; Wu, G.X. Association of vegetation patterns and environmental factors on the arid western slopes of the Helan Mountains, China. Mt. Res. Dev. 2013, 33, 323-332. [CrossRef]

74. Chafjiri, A.N.S.; Abkenar, K.T.; Navroudi, I.H.; Pourbabaei, H. Distribution of Plant Species and Their Relation to Soil Properties in Protected and Degraded Stands of Quercus macranthera in Northern Iran. Ecol. Balk. 2016, 8, 53-63.

75. Hedwall, P.-O.; Gustafsson, L.; Brunet, J.; Lindbladh, M.; Axelsson, A.-L.; Strengbom, J. Half a century of multiple anthropogenic stressors has altered northern forest understory plant communities. Ecol. Appl. 2019, 29, e01874. [CrossRef] 
76. Freeman, C.C.; Barkley, T.M. A synopsis of the genus Packera (Asteraceae: Senecioneae) in Mexico. SIDA Contrib. Bot. 1995, 16, 699-709.

77. Gobin, R.; Korboulewsky, N.; Dumas, Y.; Balandier, B. Transpiration of four common understorey plant species according to drought intensity in temperate forests. Ann. For. Sci. 2015, 72, 1053-1064. [CrossRef]

78. Canham, C.D.; Denslow, J.S.; Platt, W.J.; Runkle, J.R.; Spies, T.A.; White, P.S. Light regimes beneath closed canopies and tree-fall gaps in temperate and tropical forests. Can. J. For. Res. 1990, 20, 620-631. [CrossRef]

79. Kelemen, K.; Mihók, B.; Gálhidy, L.; Standovár, T. Dynamic response of herbaceous vegetation to gap opening in a Central European beech stand. Silva Fenn. 2012, 46, 53-65. [CrossRef]

80. Mejía, C.A.; Franco-Maass, S.; Endara, A.A.R.; Ávila, A.V. Caracterización del sotobosque en bosques densos de pino y oyamel en el Nevado de Toluca, México. Madera Bosques 2018, 24, e2431656. [CrossRef]

81. Kern, C.C.; Montgomery, R.A.; Reich, P.B.; Strong, T.F. Canopy gap size influences niche partitioning of the ground-layer plant community in a northern temperate forest. J. Plant Ecol. 2013, 6, 101-112. [CrossRef]

82. Bolton, N.W.; D'Amato, A.W. Herbaceous vegetation responses to gap size within natural disturbance-based silvicultural systems in Northeastern Minnesota, USA. Forests 2019, 10, 111. [CrossRef]

83. Vockenhuber, E.A.; Scherber, C.; Langenbruch, C.; Meißner, M.; Seidel, D.; Tscharntke, T. Tree diversity and environmental context predict herb species richness and cover in Germany's largest connected deciduous forest. Perspect. Plant Ecol. 2011, 13, 111-119. [CrossRef]

84. De Assis, A.; Coelho, R.; Da Silva, P.E.; Durigan, G. Water availability determines physiognomic gradient in an area of low-fertility soils under Cerrado vegetation. Plant Ecol. 2011, 212, 1135-1147. [CrossRef]

85. Hedwall, P.-O.; Holmström, E.; Lindbladh, M.; Felton, A. Concealed by darkness: How stand density can override the biodiversity benefits of mixed forests. Ecosphere 2019, 10, e02835. [CrossRef]

86. Tang, F.; Quan, W.; Li, C.; Huang, X.; Wu, X.; Yang, Q.; Pan, Y.; Xu, T.; Qian, C.; Gu, Y. Effects of Small Gaps on the Relationship Among Soil Properties, Topography, and Plant Species in Subtropical Rhododendron Secondary Forest, Southwest China. Int. J. Environ. Res. Public Health 2019, 16, 1919. [CrossRef]

87. Davis, K.T.; Dobrowski, S.Z.; Holden, Z.A.; Higuera, P.A.; Abatzoglou, J.T. Microclimatic buffering in forests of the future: The role of local water balance. Ecography 2018, 42. [CrossRef]

88. Adams, D.; Comrie, A. The North American Monsoon. Bull. Am. Meteorol. Soc. 1997, 78, 2197-2213. [CrossRef]

89. Villers, R.L.; García, D.V.L.; López, B.J. Evaluación de los bosques templados en México: Una aplicación en el parque nacional Nevado de Toluca. Investg. Geog. 1998, 36, 7-19. [CrossRef]

90. Fernández Nava, R. Rhamnaceae. In Flora del Bajío y de Regiones Adyacentes; Fascículo 43; Instituto de Ecología, A.C.: Pátzcuaro, Michoacán, México, 1996; pp. 5-12.

91. Obiri, J.A.; Lawes, M.J. Chance versus determinism in canopy gap regeneration in coastal scarp forest in South Africa. J. Veg. Sci. 2004, 15, 539-547. [CrossRef]

92. Hull, J.C. Plant Ecology. Encyclopedia of Ecology. Elsevier 2008, 3, 528-548. [CrossRef]

93. Mattioli, W.; Pinelli, A.; Filibeck, G.; Portoghesi, L.; Scoppola, A.; Corona, P. Relazioni tra gestione selvicolturale, tipo forestale e diversità floristica in cedui castanili. Forest@-Rev. Selv. Ecol. For. 2008, 5, 136-150.

94. Atkins, J.W.; Fahey, R.T.; Hardiman, B.S.; Gough, C.M. Forest canopy structural complexity and light absorption relationships at the subcontinental scale. J. Geophys. Res. Biogeosci. 2018, 123, 1387-1405. [CrossRef] 